\title{
Fish fauna in forested and rural streams from an ecoregion of high endemism, lower Iguaçu River basin, Brazil
}

\author{
Rosilene Luciana Delariva ${ }^{1 *}$, Mayara Pereira Neves ${ }^{2}$, Crislei Larentis ${ }^{1}$, Bruna Caroline Kotz Kliemann $^{3}$, \\ Mara Cristina Baldasso ${ }^{4}$ \& Luciano Lazzarini Wolff \\ ${ }^{1}$ Universidade Estadual do Oeste do Paraná, Centro de Ciências Biológicas e da Saúde, Rua Universitária, \\ 1619, 85819-110, Cascavel, PR, Brasil \\ ${ }^{2}$ Universidade Federal do Rio Grande do Sul, Instituto de Biociências, Av. Bento Gonçalves, 9500, \\ bloco IV-Prédio 43435, 91501-970, Porto Alegre, RS, Brasil \\ ${ }^{3}$ Universidade Estadual Paulista, Instituto de Biociências, Botucatu, R. Prof. Dr. Antônio Celso Wagner Zanin, \\ 250, 18610-307, Botucatu, SP, Brasil \\ ${ }^{4}$ Universidade Estadual do Oeste do Paraná, Programa de Pós-Graduação em Conservação e Manejo de \\ Recursos Naturais, Rua Universitária, 1619, 85819-110, Cascavel, PR, Brasil \\ *Corresponding author: Rosilene Luciana Delariva, e-mail: rosilene.delariva@hotmail.com
}

DELARIVA, R. L., NEVES, M. P., LARENTIS, C., KLIEMANN, B. C. K., BALDASSO, M. C., WOLFF, L. L. Fish fauna in forested and rural streams from an ecoregion of high endemism, lower Iguaçu River basin, Brazil. Biota Neotropica. 18(3): e20170459. http://dx.doi.org/10.1590/1676-0611-BN-2017-0459

\begin{abstract}
The fish fauna of eight streams with different land uses of their watersheds (forested and rural areas) in the lower Iguaçu River basin was inventoried, in order to evaluate the composition and species richness. The fishes were sampled quarterly from May 2015 to February 2016, using the electrofishing technique. In total, 4,239 individuals were captured, belonging to six orders, 11 families and 26 species. The orders Siluriformes and Characiformes, and the families Characidae and Trichomycteridae were the most specious. Of the total species sampled, $65 \%$ were endemic to the Iguaçu River basin, four are not described and four are non-native. As expected to the Iguaçu River basin, the inventoried fauna revealed low richness and high endemism, however was highly nested within the species composition reported for main channel of Iguaçu River and their larger tributaries. The species recorded here corresponded to a subset of $24.5 \%$ of the 106 species documented for the basin. The streams presented different faunas, with only two species (Astyanax bifasciatus and Trichomycterus stawiarski) common to both forested and rural streams. In addition, higher species richness was recorded in streams inserted in conservation units. The presence of non-native species was more frequent in rural streams. These results highlight the importance of the preservation of forested areas in the watersheds of lower Iguaçu, which presents a peculiar fish fauna, along with several threats to biodiversity such as habitat loss by intensive agriculture use.
\end{abstract}

Keywords: freshwater, ichthyofauna, inventory, Iguassu ecoregion, land use.

\section{Fauna de peixe em riachos florestados e rurais de uma ecoregião de alto endemismo, bacia do baixo rio Iguaçu, Brasil}

Resumo: A fauna de peixes foi inventariada em oito riachos com diferentes usos do entorno (áreas florestadas e rurais) na porção do baixo rio Iguaçu, em ordem para avaliar possíveis diferenças na composição e riqueza de espécies. Os peixes foram amostrados trimestralmente entre maio de 2015 e fevereiro de 2016, por meio da técnica de pesca elétrica. No total foram capturados 4239 indivíduos, pertencentes a seis ordens, 11 famílias e 26 espécies. As ordens Siluriformes e Characiformes foram as mais especiosas, assim como as famílias Characidae e Trichomycteridae. Do total de espécies amostradas, $65 \%$ foram endêmicas da bacia do rio Iguaçu, quatro foram não descritas e outras quatro foram não-nativas. Como esperado para a bacia do rio Iguaçu, a fauna inventariada revelou baixa riqueza e elevado endemismo, contudo, foi altamente aninhada dentro da composição de espécies relatada para o canal principal do rio Iguaçu e seus grandes tributários. As espécies aqui registradas corresponderam a um subconjunto de espécies de 24,5\% das 106 documentadas para a bacia. Os riachos apresentaram faunas distintas, sendo que apenas duas espécies (Astyanax bifasciatus e Trichomycterus stawiarski) foram comuns a ambos os grupos de riachos florestados e rurais. Além disso, houve maior riqueza de espécies em riachos florestados. A presença de espécies não nativas foi maior em riachos rurais. Esses resultados ressaltam a importância da preservação de áreas florestadas nas bacias do baixo rio Iguaçu, as quais apresentam uma fauna de peixes peculiar, com várias ameaças para a biodiversidade tais como a perda de habitat por intensivo uso do solo pela agricultura.

Palavras-chave: água doce, ictiofauna, inventário, ecorregião do Iguaçu, uso da terra. 


\section{Introduction}

The fish fauna of the Iguaçu River basin is one of the most emblematic and remarkable of the Neotropical region (Malabarba et al. 1998, Abell et al. 2008, Nogueira et al. 2010). While others similar large tributaries from upper Paraná River system (e.g., Paranapanema, Tietê, Grande) include more than 150 fish species (Langeani et al. 2007, Duke Energy 2008), the inventories along Iguaçu River basin have not exceeded much more than one hundred species, added those introduced (Baumgartner et al. 2012). Its low species richness is more evident in smaller spatial scales, where local fish assemblages of streams have presented between six to 12 species (Vitule \& Abilhoa 2003, Bifi et al. 2006, Abilhoa et al. 2008, Neves et al. 2015, Larentis et al. 2016), while others streams with similar magnitude from Paraná system, between 13 to 41 species (Castro et al. 2003, Delariva \& Silva 2013, Cetra et al. 2012, Vidotto-Magnoni et al. 2015).

The Iguaçu drainage also presents an enigmatic fish biogeographic history, which have evolved separately from remainder Paraná system in consequences of the Iguaçu Waterfalls formation (Garavello et al. 1997). This vicariant process isolated ancestral populations above Iguaçu Waterfalls, generating an endemic fish fauna (Zawadzki et al. 1999), especially, considering characins of the genus Astyanax (Garavello \& Sampaio 2010). Further, the endemism contributed to categorize the Iguaçu River basin as a distinct World Ecoregion of freshwater fish distribution (Abell et al. 2008), within the broader ichthyofaunistic province of Paraná-Platense system (Géry 1969). The barrier imposed by falls to migratory movement of large reofilic species (Agostinho et al. 2003), and the compartmentalization along the Iguaçu River basin (Petri \& Fulfaro 1983), have been evocated to explain the relative specie-poor fish assemblages and endemism of this basin (Sampaio 1988, Garavello \& Sampaio 2010).

Despite of fish fauna singularities, the high stretches of Iguaçu River basin have been hardly impacted by industrial and urban pollution (Agostinho \& Gomes 1997, Yamamoto et al. 2016), while hydroelectric dams, constructed in cascades, represent the main threat to fish fauna at the lower Iguaçu River and its tributaries (Agostinho et al. 2008, 2016). The construction of the low Iguaçu dam at its last segment above the falls (ANEEL 2017), has imminent potential to negative impacts, both on the endemic fishes and on the boundaries of Iguaçu National Park (UNESCO 2012). Furthermore, the fish fauna located upstream, at headwater regions of lower Iguaçu River basin, has been impacted by agricultural activities (Larentis et al. 2016, Nimet et al. 2017) and remaining under sampled when compared with reservoirs of its principal channel (Baumgartner et al. 2006, 2012).

The Western region of Paraná state is located at the intersection of three hydrographic basins (i.e., Piquiri, Paraná III and Iguaçu River), and stands out, having Cascavel as polo city, as one of the main regions of the state and of Brazil in the grains production (IBGE 2015). To the south of the hydrographical divisor of these there basins are streams that flows to lower Iguaçu River, whose ichthyofauna have been only recently studied (Neves et al. 2015, Larentis et al. 2016). Due to the historical process of land use and occupation, these streams present different percentages of vegetal cover among their watersheds. The use gradient extends from rural streams, with intense agricultural activity (IBGE 2015, Yamamoto et al. 2016), to preserved streams located partially or integrally within conservation units, like those into the Iguaçu National Park (INP) (Neves et al. 2015).
In this context, the present inventory consists in the first check list of the fish fauna of lower Iguaçu River basin, what contemplates eight low order streams with different land uses (from seven to $100 \%$ of vegetal cover of its watershed). This sampling design also allowed to determinate the species richness in function of the watershed use and to discuss the similarities among the local fish faunas in relation to other headwater streams and to the principal channel of the lower Iguaçu River basin. In addition, because the impacts on Iguaçu system might represent global extinctions due to higher endemism, this inventory generated information to be used as a tool to sustainable management and restoration of the rural streams.

\section{Material and Methods}

\section{Study area}

The Iguaçu River basin encompasses an area of $55.108 .04 \mathrm{~km}^{2}$ in the Paraná state (Parolin et al. 2010) and is subdivided into three hydrographical units: upper, middle, and lower Iguaçu River. Iguaçu Waterfalls is located at its lower course, in the municipality of Foz do Iguaçu, and is considered the largest falls in volume of water on the planet. The waterfalls through a deep crevice, with a gap of 72 meters and an average volume of $1.551 \mathrm{~m}^{3} / \mathrm{second}$ (SEMA 2013). In particular, the lower Iguaçu River basin has undergone a rapid transformation from the 1970s, due to the mechanization and agricultural expansion (Campos 1998). On the Brazilian side of the Iguaçu Waterfalls and vicinity of the Iguaçu River in this region, is situated the Iguaçu National Park, a main conservation unit that constitutes the largest remnant area of preservation of semideciduous forest of the Paraná State. Besides forested areas, the main economic activity in this region is agriculture, especially the cultivation of soybeans and corn, and pastures (IBGE 2015), which were the prevailing scenario in the vicinity of the sampled streams.

The watersheds of the studied streams drain directly or indirectly into the low Iguaçu River, and are located within or on the border of preservation (sites 1, 2 and 6 on the map), forested (site 7) and cultivated areas (sites 3, 4, 5 and 8) (Figures 1 and 2). The calculation of the percentage of vegetation cover as well as agricultural areas was obtained through the Google Earth Pro program for the delimitation of the watershed area $\left(\mathrm{km}^{2}\right)$. By establishing the point where the elevation of the land begins to decline, several points were defined for the definition of a polygon of the area of the watershed, and categorizations were made according to the following criteria: area with vegetation (remnants of native forest and presence of riparian forest within the watershed area); rural area (defined by the presence of areas of pastures, cereal crops and monocultures, and rural constructions). Thus, the streams were classified in: forested when they were inserted in preservation areas or when had more than $50 \%$ of vegetation; and rural when presented more than $50 \%$ of the watershed within cultivated area. The main physical and hydrological characteristics of the sampled streams and geographical coordinates are shown in Table 1.

\section{Data collection}

The samplings of the fish fauna were performed quarterly from May 2015 to February 2016 in eight streams, varying from $1^{\text {st }}$ to $3^{\text {rd }}$ orders, but with similar dimensions (Table 1). Fish were collected by electrofishing technique (output voltage varied from 400 to $600 \mathrm{~V}$ ), with 


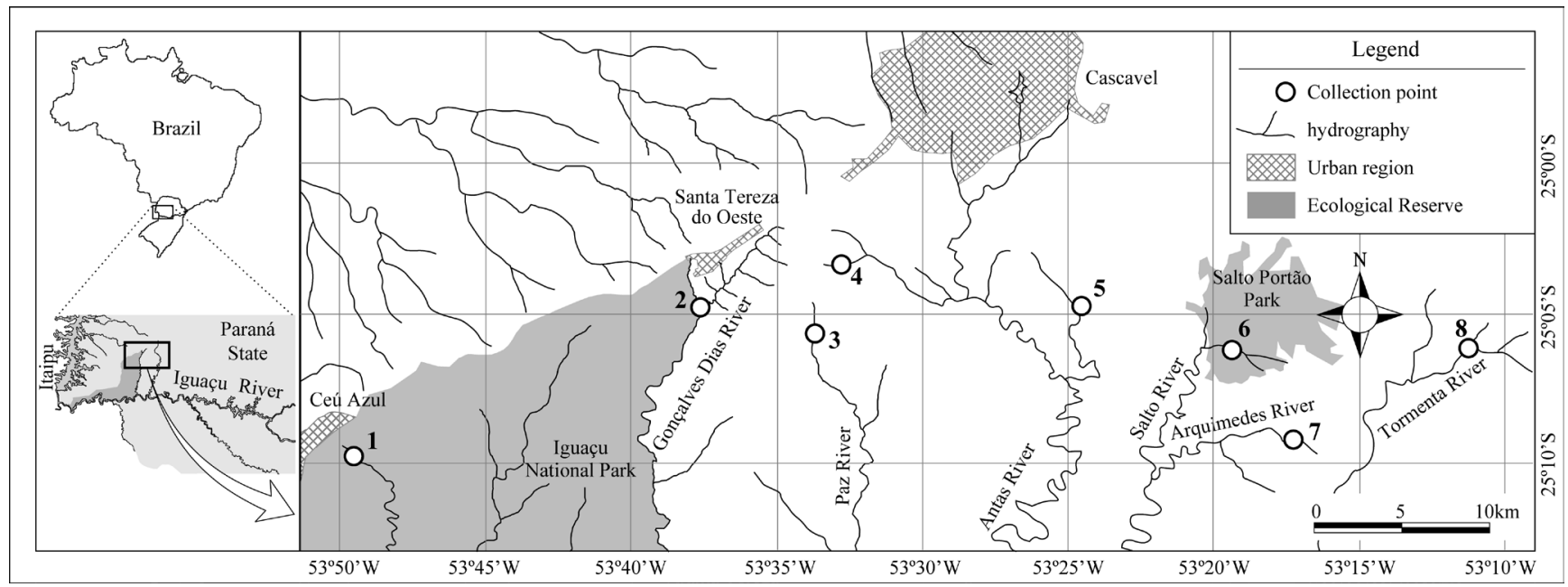

Figure 1. Map of study area in the lower Iguaçu River basin, Paraná State, Brazil.

three paces of 40 minute in 50 meters length at each stream. The reaches were blocked (nets with mesh size $0.5 \mathrm{~mm}$ ) to prevent the escape of fish. After samplings, specimens were sacrificed in a solution of clove oil (Eugenol, 2 drops per liter; $c f$. American Veterinary Medical Association 2001 ), and fixed in 10\% formalin and then preserved in $70 \%$ alcohol.

Specimens were identified according to Baumgartner et al. (2012), Garavello et al. (2012), Garavello \& Sampaio (2010) and Graça \& Pavanelli (2007). Fishes were categorized based on their distribution in the Iguaçu River basin, following Baumgartner et al. (2012), as endemic (species with distribution restricted to the Iguaçu River basin), native (species indigenous from the Iguaçu River basin, but not restricted to it), and non-native (species introduced to the Iguaçu River basin) (Table 2). The popular names followed Baumgartner et al. (2012) (Table 2). Voucher specimens were deposited in the Fish Collection of Nupélia (Núcleo de Pesquisas em Limnologia, Ictiologia e Aquicultura), Universidade Estadual de Maringá - UEM, Paraná State, Brazil. Fish were collected with authorization from Instituto Chico Mendes de Conservação da Biodiversidade - (ICMBio) (license numbers 30182, 25039-1), and approved by Ethics Committee on Animal Use of the Universidade Estadual do Oeste do Paraná (CEUA) in accordance with protocols in their ethical and methodological aspects, for the use of fish.

\section{Results}

A total of 4,239 specimens were recorded, comprising 26 species (Figures 3 and 4), belonging to 11 families and six orders (Table 2). The most species-rich orders were Siluriformes (12), followed by Characiformes (nine) and Cyprinodontiformes (two) (Figure 5). Other orders were represented only by one species each. The most representative family was Characidae (seven species), followed by Trichomycteridae (five species), Heptapteridae and Loricariidae (three species). Poeciliidae was represented by two species and other families with one species each (Figure 6). Four species were identified only to genus level (Heptapterus sp., Hoplias sp. 1, Trichomycterus sp. 1, Trichomycterus sp. 2), sensu Baumgartner et al. (2012). Regarding the origin of the species, 17 (65\%) were endemic species to the Iguaçu River basin and four were non-native (Poecilia reticulata, Gymnotus sylvius, Synbranchus marmoratus and Oreochromis niloticus (Table 2).
The Nene stream (S4) recorded the higher richness (14 species), followed by Jumelo (S2), Manoel Gomes (S1) and Pedregulho (S6) (13 species each), Arquimedes (S7) and Bom Retiro (S5) (10 species), Rio da Paz (S3) (nine) and Tormenta (S8), with only five species. Considering the set of streams together (four forested and four rural), species richness was higher in forested streams (22 species) than rural streams (18 species).

The fish fauna was characterized by small-sized specimens, considering that about $80 \%$ had a maximum standard length (SL) lower than $150 \mathrm{~mm}$ (Table 2). The most frequent species were Astyanax bifasciatus, Trichomycterus stawiarski and Ancistrus mullerae that occurred in all sites, except the last species that does not occurred in S8. Eight species had their occurrences only in forested streams: Astyanax dissimilis and Corydoras carlae were recorded exclusively at S1; Bryconamericus pyahu and T. mboycy at S2, while Heptapterus sp. and at Hoplias sp. 1 were respectively exclusive to S7 and S6. Hisonotus yasi occurred in two (S1, S7) and Phalloceros harpagos in three forested sites (S2, S6 and S7). Only four species were exclusive to rural streams: Characidium travassosi was represented by a single individual caught on S8; Astyanax lacustris (two individuals) was exclusive to S4, Poecilia reticulata only in the S5 and Gymnotus sylvius was recorded in three streams (S3, S4 and S5). In addition, considering all the streams, four non-native species were recorded, and except for Oreochromis niloticus, the others occurred only in rural streams.

\section{Discussion}

The present study registered a total of 26 species, with fish richness ranging from five to 14 species in the eight streams studied. This pattern of low species richness, associated with high endemism, has also characterized the ichthyofauna of other low-order streams in Iguaçu River basin (Ingenito et al. 2004, Bifi et al. 2006, Abilhoa et al. 2008). These findings distinguish the fish fauna of headwaters of Iguaçu River basin from others similar streams of Paraná River system, with higher species richness (Araújo et al. 2011, Marceniuk et al. 2011, Hoffmann et al. 2015, Vidotto-Magnoni et al. 2015, Cetra et al. 2016, Frota et al. 2016a). Lower fish richness was also verified by Larentis et al. (2016) in streams flowing upstream Iguaçu Waterfalls, when compared 

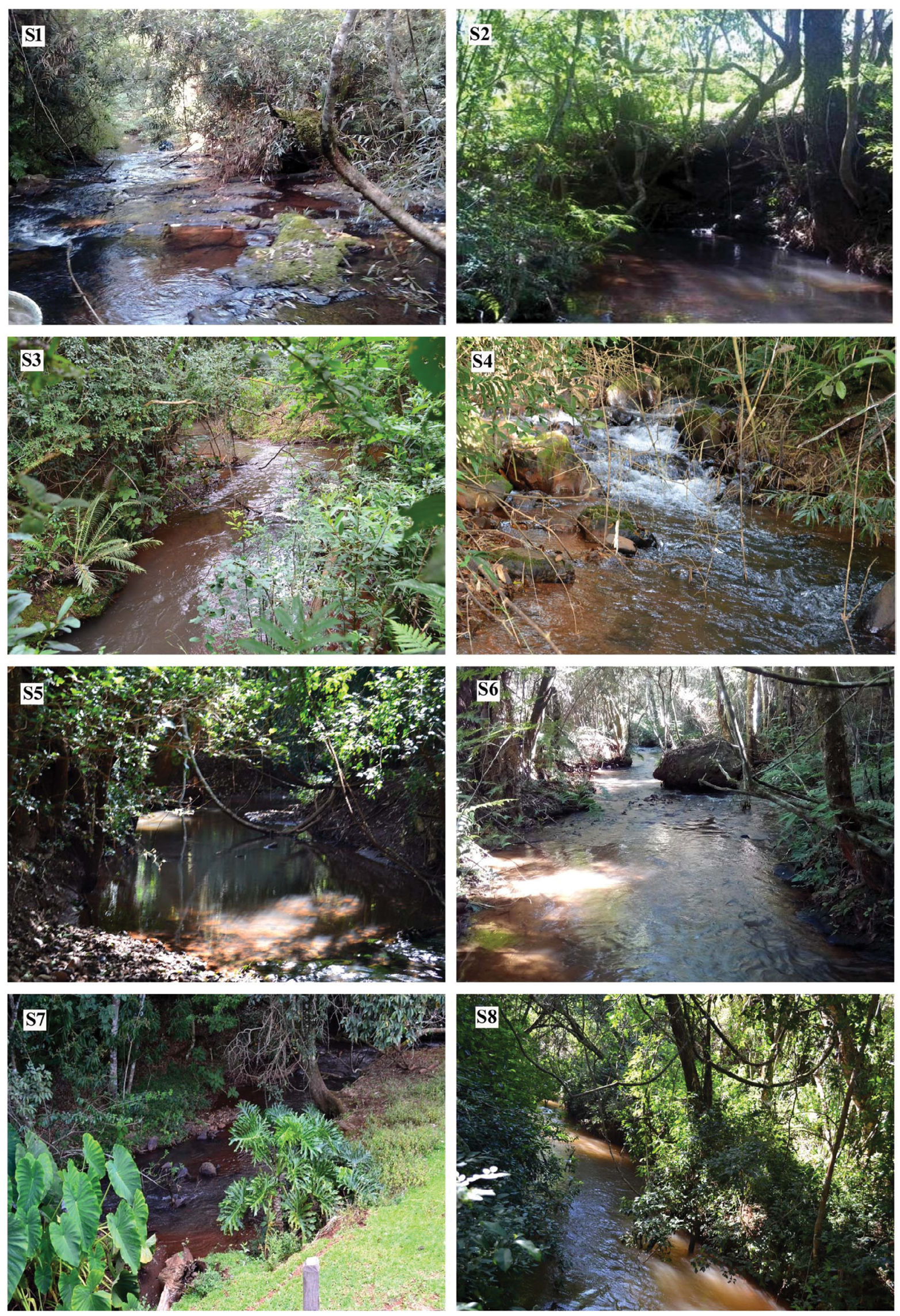

Figure 2. Reaches sampled in the streams of the lower Iguaçu River basin. S1= Manoel Gomes, S2 = Jumelo, S3 = Rio da Paz, S4 = Nene, S5 Bom Retiro, S6 = Pedregulho, S7 = Arquimedes and S8 = Tormenta. 
Table 1. Characteristics of the sampled sites in eight streams of Iguaçu River basin, Paraná State, Brazil. Substrate predominant (categorizations were made according with the bottom substrate sizes $)=$ boulders $(>80 \mathrm{~mm}$ diameter $)$, cobbles $(50-80 \mathrm{~mm})$, pebbles $(25-50 \mathrm{~mm})$, gravel $(5-25 \mathrm{~mm})$, sand $(<5 \mathrm{~mm})$ and clay $($ silt particles $)$. Land use $=$ forested streams $(\mathrm{F})$ and rural $(\mathrm{R})$.

\begin{tabular}{|c|c|c|c|c|c|c|c|c|c|c|c|}
\hline Sites & $\begin{array}{l}\text { Stream } \\
\text { name }\end{array}$ & $\begin{array}{l}\text { Latitude (S)/ } \\
\text { Longitude } \\
(\mathbf{W})\end{array}$ & $\begin{array}{l}\text { Average } \\
\text { depth } \\
\text { (m) }\end{array}$ & $\begin{array}{l}\text { Average } \\
\text { width } \\
\text { (m) }\end{array}$ & $\begin{array}{l}\text { Average } \\
\text { flow } \\
\left(\mathbf{m} . \mathbf{s}^{-1}\right)\end{array}$ & $\begin{array}{c}\text { Substrate } \\
\text { predominant }\end{array}$ & $\begin{array}{l}\text { Vegetal } \\
\text { cover } \\
(\%)\end{array}$ & $\begin{array}{l}\text { Rural } \\
\text { area } \\
(\%)\end{array}$ & $\begin{array}{l}\text { Urban } \\
\text { area } \\
(\%)\end{array}$ & $\begin{array}{l}\text { Land } \\
\text { use }\end{array}$ & Others characteristics \\
\hline $\mathrm{S} 1$ & $\begin{array}{l}\text { Manoel } \\
\text { Gomes }\end{array}$ & $\begin{array}{c}25^{\circ} 09^{\prime} 43.4^{\prime \prime} / \\
53^{\circ} 49^{\prime} 46.1^{\prime \prime}\end{array}$ & 0.17 & 4.6 & 0.21 & $\begin{array}{l}\text { Boulders/ } \\
\text { cobbles }\end{array}$ & 100 & 0 & 0 & $\mathrm{~F}$ & $\begin{array}{l}\text { Inserted into Iguaçu National Park } \\
\text { (INP) and surrounded by dense } \\
\text { native forest. Presence of a } 5 \text { meters } \\
\text { waterfall upstream the sampling site. }\end{array}$ \\
\hline $\mathrm{S} 2$ & Jumelo & $\begin{array}{c}25^{\circ} 04^{\prime} 46.6^{\prime \prime} / \\
53^{\circ} 37^{\prime} 26.4^{\prime \prime}\end{array}$ & 0.21 & 3.4 & 0.30 & Pebbles/gravel & 62 & 25 & 13 & $\mathrm{~F}$ & $\begin{array}{l}\text { Right bank limiting INP, while } \\
\text { left bank with reduced riparian } \\
\text { vegetation, erosion areas and } \\
\text { human occupation (i.e. houses and } \\
\text { agriculture). }\end{array}$ \\
\hline S3 & Rio da Paz & $\begin{array}{c}25^{\circ} 05^{\prime} 38.1^{\prime \prime} / \\
53^{\circ} 33^{\prime} 24.8^{\prime \prime}\end{array}$ & 0.20 & 3.8 & 0.33 & Sand/gravel & 20 & 80 & 0 & $\mathrm{R}$ & $\begin{array}{l}\text { Reduced riparian forest and } \\
\text { predominance of monoculture } \\
\text { areas (soybean and corn) in the } \\
\text { surroundings. Presence of exogenous } \\
\text { material (car tires) on the riverbed. }\end{array}$ \\
\hline S4 & Nene & $\begin{array}{c}25^{\circ} 03^{\prime} 25.6^{\prime \prime} / \\
53^{\circ} 32^{\prime} 28.9^{\prime \prime}\end{array}$ & 0.19 & 4.1 & 0.22 & Clay/cobbles & 7 & 93 & 0 & $\mathrm{R}$ & $\begin{array}{l}\text { Reduced riparian vegetation with } \\
\text { spaced trees, dense bamboos and } \\
\text { intensive monoculture areas. }\end{array}$ \\
\hline S5 & Bom Retiro & $\begin{array}{c}25^{\circ} 04^{\prime} 47.4^{\prime \prime} / \\
53^{\circ} 24^{\prime} 02.9^{\prime \prime}\end{array}$ & 0.18 & 3.9 & 0.32 & Pebbles/gravel & 27 & 73 & 0 & $\mathrm{R}$ & $\begin{array}{l}\text { Within monocultures and aviculture } \\
\text { farms, narrowed/ degraded riparian } \\
\text { vegetation. Presence of exogenous } \\
\text { material (plastic and animal } \\
\text { carcasses) on the riverbed. }\end{array}$ \\
\hline S6 & Pedregulho & $\begin{array}{c}25^{\circ} 06^{\prime} 6.10^{\prime \prime} / \\
53^{\circ} 18^{\prime} 41.3^{\prime \prime}\end{array}$ & 0.21 & 4.2 & 0.43 & $\begin{array}{l}\text { Cobbles/ } \\
\text { pebbles }\end{array}$ & 75 & 25 & 0 & $\mathrm{~F}$ & $\begin{array}{l}\text { Inserted in a Private Natural } \\
\text { Reserve, with native forest, but with } \\
\text { grasslands and a fish farming in their } \\
\text { left bank. }\end{array}$ \\
\hline S7 & Arquimedes & $\begin{array}{l}25^{\circ} 09^{\prime} 10.6^{\prime \prime} / \\
53^{\circ} 16^{\prime} 39.4^{\prime \prime}\end{array}$ & 0.24 & 3.2 & 0.26 & $\begin{array}{l}\text { Boulders/ } \\
\text { cobbles }\end{array}$ & 66 & 34 & 0 & $\mathrm{~F}$ & $\begin{array}{l}\text { Dense riparian cover on the left bank } \\
\text { and human occupation (i.e. houses } \\
\text { and animal farming) on the right } \\
\text { bank. Some sedimented reaches. }\end{array}$ \\
\hline S8 & Tormenta & $\begin{array}{c}25^{\circ} 06^{\prime} 08.8^{\prime \prime} / \\
53^{\circ} 08^{\prime} 10.1^{\prime \prime}\end{array}$ & 0.34 & 3.8 & 0.35 & Boulders/clay & 18 & 82 & 0 & $\mathrm{R}$ & $\begin{array}{l}\text { Within monocultures and reduced } \\
\text { riparian cover with presence of } \\
\text { exotic trees (i.e. Pinus sp.). Clayed } \\
\text { banks and unstable. }\end{array}$ \\
\hline
\end{tabular}

to those that flows downstream it. This low richness, similar to our results, highlights the abrupt differentiations of the fish fauna between the Iguaçu drainage below falls and their upstream reaches, above the falls (Garavello et al. 1997, Zawadzki et al. 1999).

The other singular pattern registered for the fish assemblage inventoried here was its high nestedness within species composition reported by Baumgartner et al. (2012) to principal low Iguaçu River channel and their larger tributaries. On the other hand, these results represent a quasi-perfect species subset, corresponding to $24.5 \%$ of the 106 species mentioned in Baumgartner et al. (2012). Frota et al. (2016b) registered similar low fish richness $(\mathrm{n}=27)$ and higher fish composition similarities (above 45\%), with the principal channel to streams of the two larger tributaries of the right bank (Jordão and Areia) of low Iguaçu River basin. This high similarity between local and broader spatial distributions could be explained by: i) lacking larger migratory species in Iguaçu River basin that are deeper channel dwellers in the Paraná River and others tributaries (Agostinho et al. 2003, 2008); ii) the wide ability of the characins of genus Astyanax to colonize practically all environments of basin, including large and small inland water or even reservoirs. This genus present broad distribution in low Iguaçu River basin (Garavello \& Sampaio 2010), pronounced trophic plasticity
(Wolff et al. 2009, Delariva et al. 2013), and were captured here, with high abundances in all streams independently of physiographic features and land use.

The lack of a restrict occurrence found in the fishes studied herein contrasts, for example, to drainages of the upper Paranapanema River basin (São Paulo state), where from 70 to $80 \%$ of fish species inhabit preferentially headwater streams, instead of higher order courses (Oyakawa \& Menezes 2011). However, there is some apparent bias in knowledge of Iguaçu streams fish fauna, because greater attention had been given to inventories in or near to reservoirs areas (Garavello et al. 1997, Baumgartner et al. 2006, 2012). In addition, the studies of Iguaçu ichthyofauna have been smaller when compared to the upper Paraná basin (Langeani et al. 2007, Cetra et al. 2016), not encompassing large check lists of this region. Besides, there is yet the need of a compilation with an accurate systematic review to stream fish fauna of local regions, because some apparently species with restricted occurrence, showed broader distribution in more detailed studies (Frota et al. 2016b).

The predominance of Siluriformes and Characiformes is very well documented for Iguaçu River basin. For example, many previous studies already demonstrated that this pattern not occur only in low Iguaçu system (Bifi et al. 2006, Baumgartner et al. 2012, Larentis et al. 2016), 
Table 2. List of fish species and their respective occurrences at sampling site in eight streams of lower Iguaçu River basin. Systematic positions were based on Nelson (2006) to all orders, and Siluriformes families; Reis et al. (2003) to other families, except Characidae that follow Mirande (2009). The column "Origin" refers to species classified as endemic (EN), native $(\mathrm{N})$ and non-native $(\mathrm{NN})$ to the Iguaçu River basin (Baumgartner et al. 2012). SL max = maximum standard length recorded; NA = numerical abundance; Vouchers specimens: individuals deposited in Fish Collection of Núcleo de Pesquisas em Limnologia, Ictiologia e Aquicultura.

\begin{tabular}{|c|c|c|c|c|c|c|c|c|c|c|c|c|c|}
\hline Táxon & Popular name & $\begin{array}{c}\text { SL } \\
\text { max } \\
\text { (cm) }\end{array}$ & Origin & \multicolumn{8}{|c|}{ Sites } & NA & $\begin{array}{c}\text { Voucher } \\
\text { specimens }\end{array}$ \\
\hline \multicolumn{14}{|l|}{ CHARACIFORMES } \\
\hline \multicolumn{14}{|l|}{ Crenuchidae } \\
\hline Characidium travassosi Melo, Buckup \& Oyakawa 2016 & "charutinho" & 4.6 & EN & & & & & & & & $\mathrm{x}$ & 1 & 19033 \\
\hline \multicolumn{14}{|l|}{ Characidae } \\
\hline Astyanax bifasciatus Garavello \& Sampaio 2010 & $\begin{array}{l}\text { "lambari-do rabo } \\
\text { vermelho" }\end{array}$ & 11.6 & EN & $\mathrm{x}$ & $\mathrm{x}$ & $\mathrm{x}$ & $\mathrm{x}$ & $\mathrm{x}$ & $\mathrm{x}$ & $\mathrm{x}$ & $\mathrm{x}$ & 910 & 19028 \\
\hline Astyanax dissimilis Garavello \& Sampaio 2010 & "lambari" & 9.5 & EN & $\mathrm{x}$ & & & & & & & & 2 & 19024 \\
\hline Astyanax gymnodontus (Eigenmann 1911) & "lambari" & 10.8 & EN & $\mathrm{x}$ & $\mathrm{x}$ & & $\mathrm{x}$ & & & $\mathrm{x}$ & & 104 & 19025 \\
\hline Astyanax minor Garavello \& Sampaio 2010 & "lambari" & 8.5 & EN & $\mathrm{x}$ & $\mathrm{x}$ & $\mathrm{x}$ & & & $\mathrm{x}$ & & & 86 & 19026 \\
\hline Hoplias sp. 1 & "traíra" & 20.0 & $\mathrm{~N}$ & & & & & & $\mathrm{x}$ & & & 4 & 19037 \\
\hline \multicolumn{14}{|l|}{ SILURIFORMES } \\
\hline \multicolumn{14}{|l|}{ Trichomycteridae } \\
\hline Trichomycterus davisi (Haseman 1911) & "candiru" & 9.2 & $\mathrm{~N}$ & $\mathrm{x}$ & & $\mathrm{x}$ & $\mathrm{x}$ & $\mathrm{x}$ & $\mathrm{x}$ & $\mathrm{x}$ & $\mathrm{x}$ & $\mathrm{x}$ & 19054 \\
\hline Trichomycterus mboycy Wosiacki \& Garavello 2004 & "candiru" & 5.2 & EN & & $\mathrm{x}$ & & & & & & & 1 & 19051 \\
\hline Trichomycterus stawiarski (Miranda Ribeiro 1968) & "candiru" & 9.7 & EN & $\mathrm{x}$ & $\mathrm{x}$ & $\mathrm{x}$ & $\mathrm{x}$ & $\mathrm{x}$ & $\mathrm{x}$ & $\mathrm{x}$ & $\mathrm{x}$ & 491 & 19049 \\
\hline Trichomycterus sp. 1 & "candiru" & 9.6 & EN & & $\mathrm{x}$ & & $\mathrm{x}$ & $\mathrm{x}$ & & & $\mathrm{x}$ & 197 & 19053 \\
\hline Trichomycterus sp. 2 & "candiru" & 6.1 & EN & $\mathrm{x}$ & $\mathrm{x}$ & & $\mathrm{x}$ & & $\mathrm{x}$ & & & 105 & 19056 \\
\hline \multicolumn{14}{|l|}{ Callichtyidae } \\
\hline \multicolumn{14}{|l|}{ Heptapteridae } \\
\hline Rhamdia branneri Haseman 1911 & "jundiá" & 20.7 & EN & $\mathrm{x}$ & $\mathrm{x}$ & $\mathrm{x}$ & $\mathrm{x}$ & & $\mathrm{x}$ & $\mathrm{x}$ & & 185 & 19044 \\
\hline Rhamdia voulezi Haseman 1911 & "jundiá" & 16.6 & EN & $\mathrm{x}$ & & $\mathrm{x}$ & $\mathrm{x}$ & $\mathrm{x}$ & $\mathrm{x}$ & $\mathrm{x}$ & & 20 & 19043 \\
\hline \multicolumn{14}{|l|}{ GYMNOTIFORMES } \\
\hline \multicolumn{14}{|l|}{ Gymnotidae } \\
\hline Gymnotus sylvius Albert \& Fernandes-Matioli 1999 & "morenita" & 27.0 & NN & & & $\mathrm{x}$ & $\mathrm{x}$ & $\mathrm{x}$ & & & & 26 & 19035 \\
\hline \multicolumn{14}{|l|}{ CYPRINODONTIFORMES } \\
\hline Poeciliidae & & & & & & & & & & & & & \\
\hline Phalloceros harpagos Lucinda 2008 & "guaru" & 4.7 & $\mathrm{~N}$ & & $\mathrm{x}$ & & & & $\mathrm{x}$ & $\mathrm{x}$ & & 320 & 19040 \\
\hline Poecilia reticulata Peters 1859 & "guaru" & 3.4 & $\mathrm{NN}$ & & & & & $\mathrm{x}$ & & & & 119 & 19041 \\
\hline SYNBRANCHIFORMES & & & & & & & & & & & & & \\
\hline Synbranchidae & & & & & & & & & & & & & \\
\hline Synbranchus marmoratus Bloch 1795 & "muçum" & 39.7 & NN & & $\mathrm{x}$ & & & $\mathrm{x}$ & & & & 5 & 19047 \\
\hline PERCIFORMES & & & & & & & & & & & & & \\
\hline Cichlidae & & & & & & & & & & & & & \\
\hline Oreochromis niloticus (Linnaeus, 1758) & "tilápia do nilo" & 4.5 & NN & & & & $\mathrm{x}$ & & $\mathrm{x}$ & & & 2 & 19048 \\
\hline Richness/Total abundance & & & & 13 & 13 & 9 & 14 & 10 & 13 & 10 & 5 & 4,239 & \\
\hline
\end{tabular}


Fish fauna in streams of ecoregion Iguaçu River

A
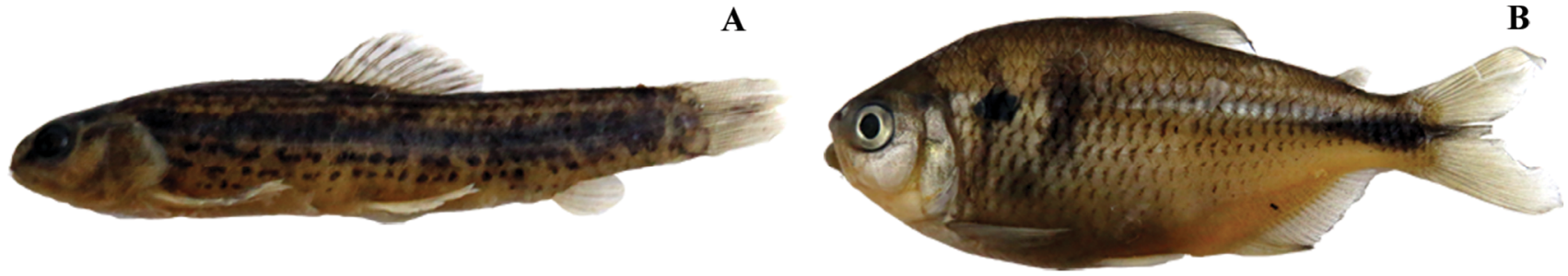

C
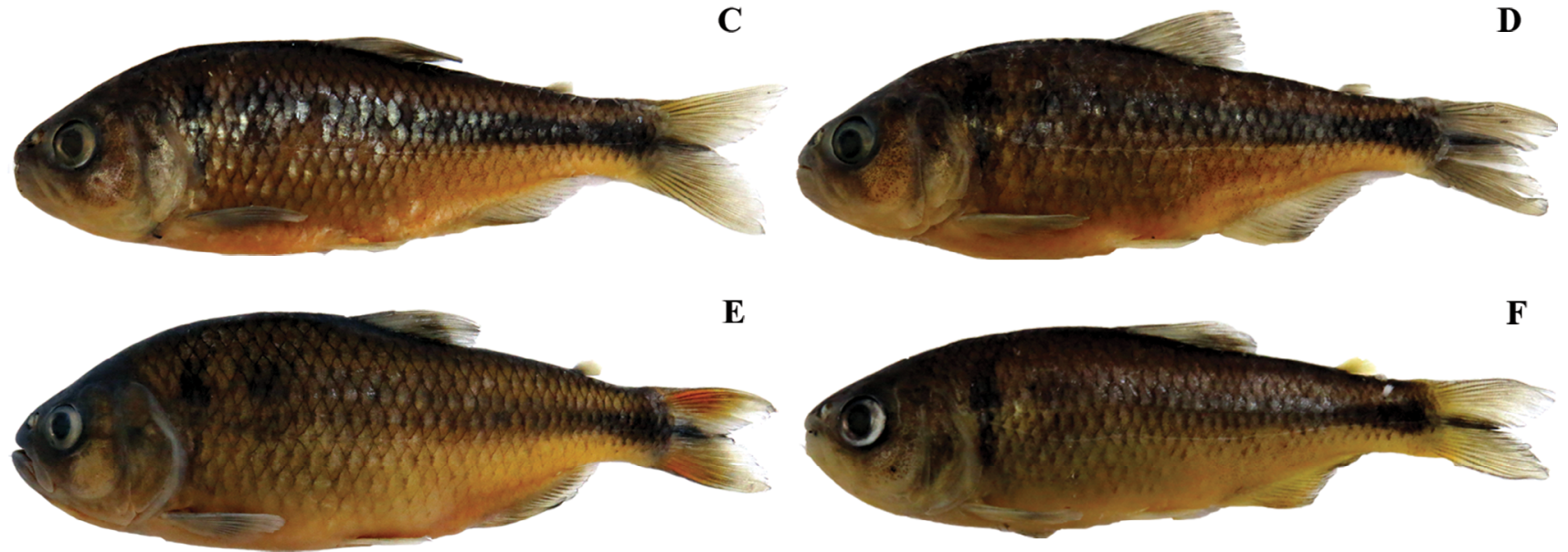

G
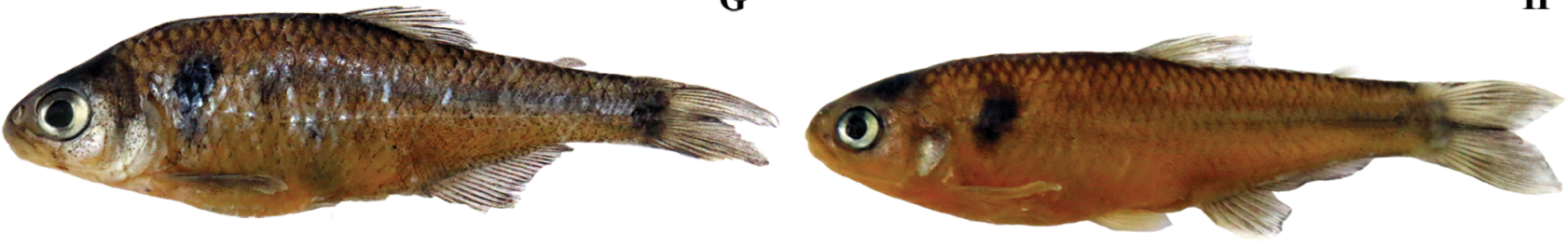

I

J
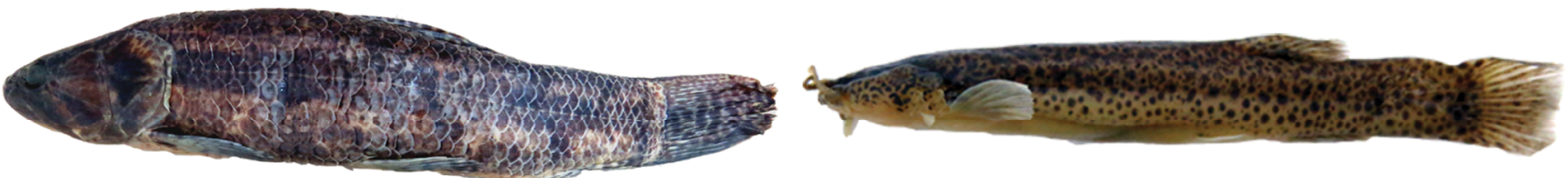

K

L
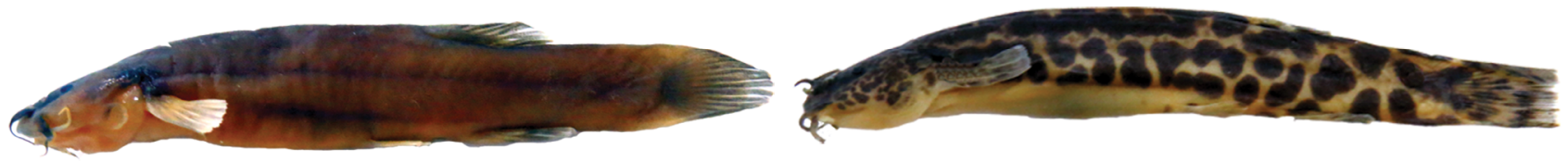

M
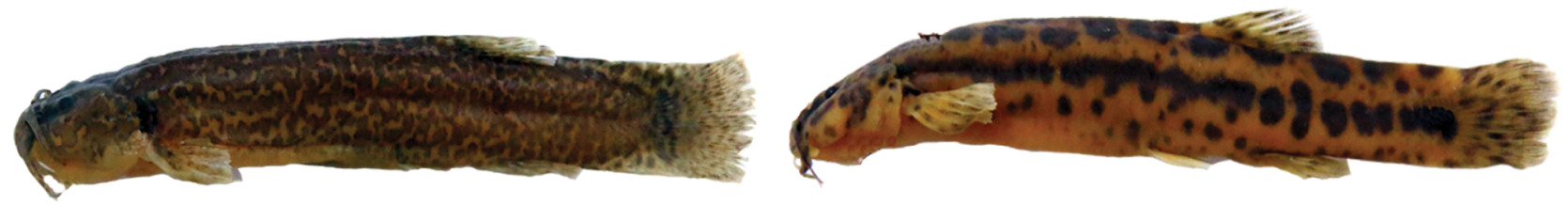

Figure 3. Representative specimens of fish species of the streams of the lower Iguaçu River basin. The standard length (SL-mm) of the exemplar pictured is presented after the name of species. A) Characidium travassosi, $47.0 \mathrm{~mm}$; B) Astyanax lacustris, $76.1 \mathrm{~mm}$; C) Astyanax bifasciatus, $72.0 \mathrm{~mm}$; D) Astyanax dissimilis, $98.0 \mathrm{~mm}$; E) Astyanax gymnodontus, $81.1 \mathrm{~mm}$; F) Astyanax minor, $69.0 \mathrm{~mm}$; G) Bryconamericus ikaa, $42.0 \mathrm{~mm}$; H) Bryconamericus pyahu, $32.0 \mathrm{~mm}$; I) Hoplias sp. 1, $201.0 \mathrm{~mm}$; J) Trichomycterus davisi, $48.0 \mathrm{~mm}$; K) Trichomycterus mboycy, $45.0 \mathrm{~mm}$; L) Trichomycterus stawiarski, $59.0 \mathrm{~mm}$; M) Trichomycterus sp. 1, $44.1 \mathrm{~mm}$; N) Trichomycterus sp. 2, 36.0 mm. 


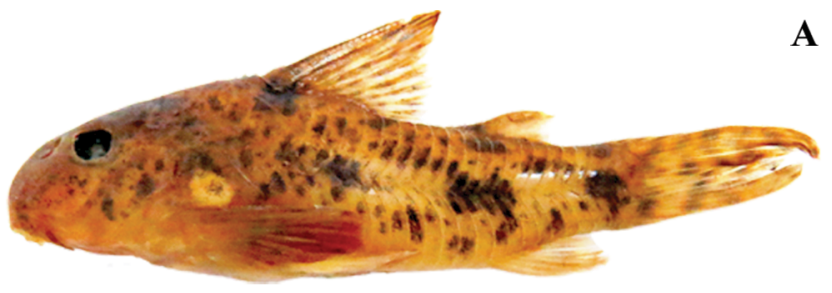

A

B

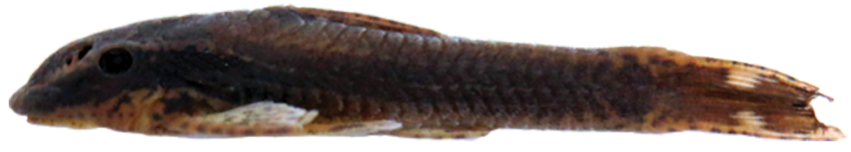

C

D
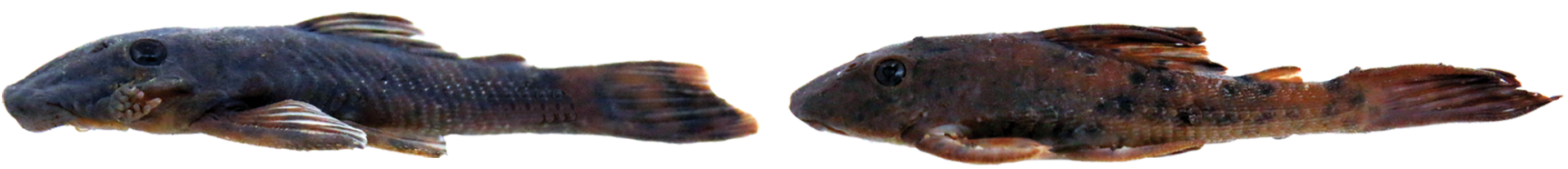

E

G
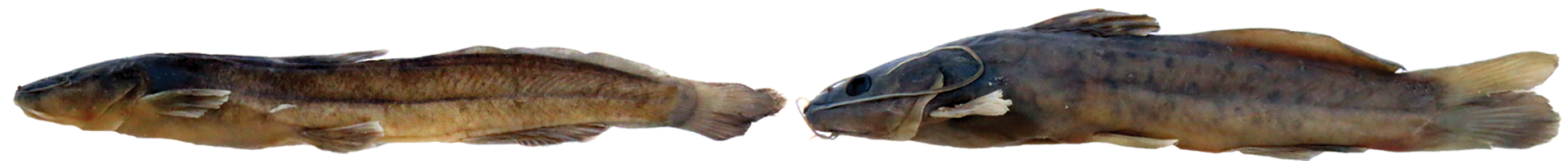

H
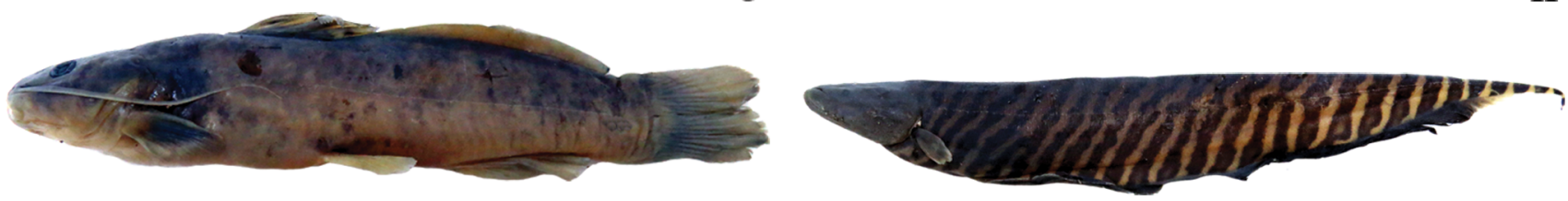

I
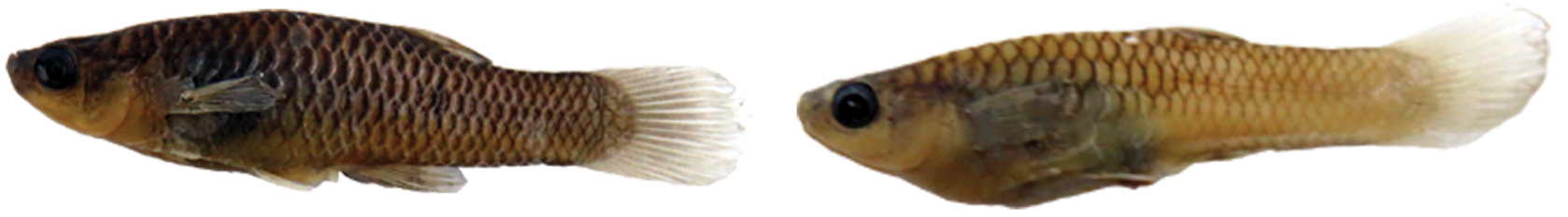

K

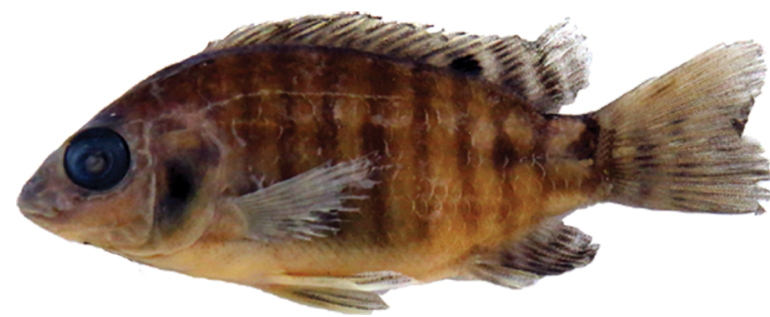

L

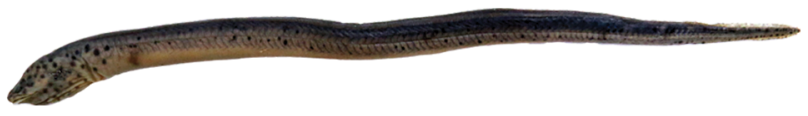

Figure 4. Representative specimens of fish species of the streams of the lower Iguaçu River basin. The standard length (SL-mm) of the exemplar pictured is presented after the name of species. A) Corydoras carlae, $32.7 \mathrm{~mm}$; B) Hisonotus yasi, $31.0 \mathrm{~mm}$; C) Ancistrus mullerae, $36.0 \mathrm{~mm}$; D) Hypostomus derbyi, $52.0 \mathrm{~mm}$; E) Heptapterus sp., $118.6 \mathrm{~mm}$; F) Rhamdia branneri, $121.0 \mathrm{~mm}$; G) Rhamdia voulezi, $98.6 \mathrm{~mm}$; H) Gymnotus sylvius, $145.0 \mathrm{~mm}$;) Phalloceros harpagos, 40.2 mm; J) Poecilia reticulata, $19.0 \mathrm{~mm}$; K) Synbranchus marmoratus, $195.0 \mathrm{~mm}$; L) Oreochromis niloticus, $43.0 \mathrm{~mm}$. 


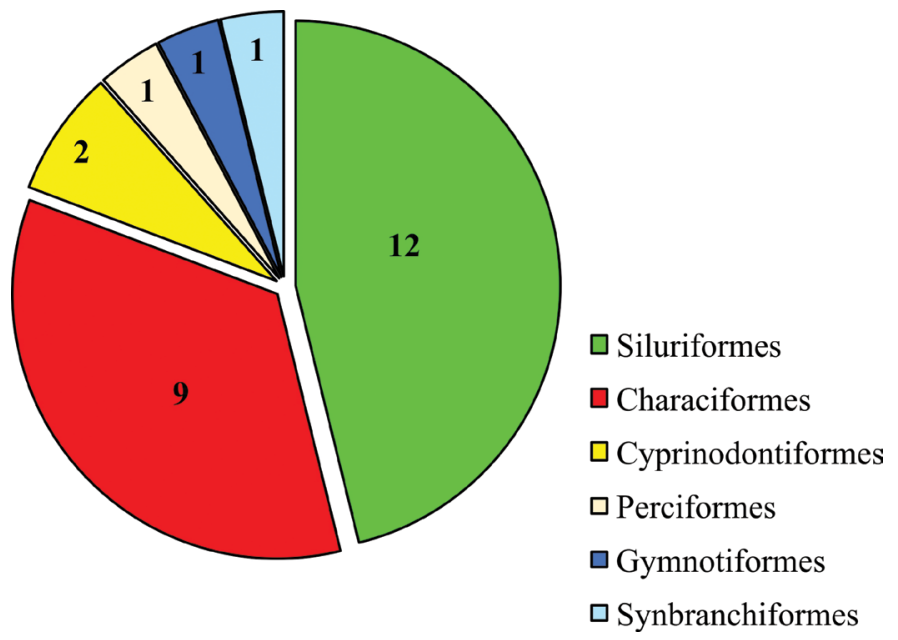

Figure 5. Proportional species richness in the six fish orders recorded in eight streams of the lower Iguaçu River basin. In side numbers represents the absolute richness to each order.

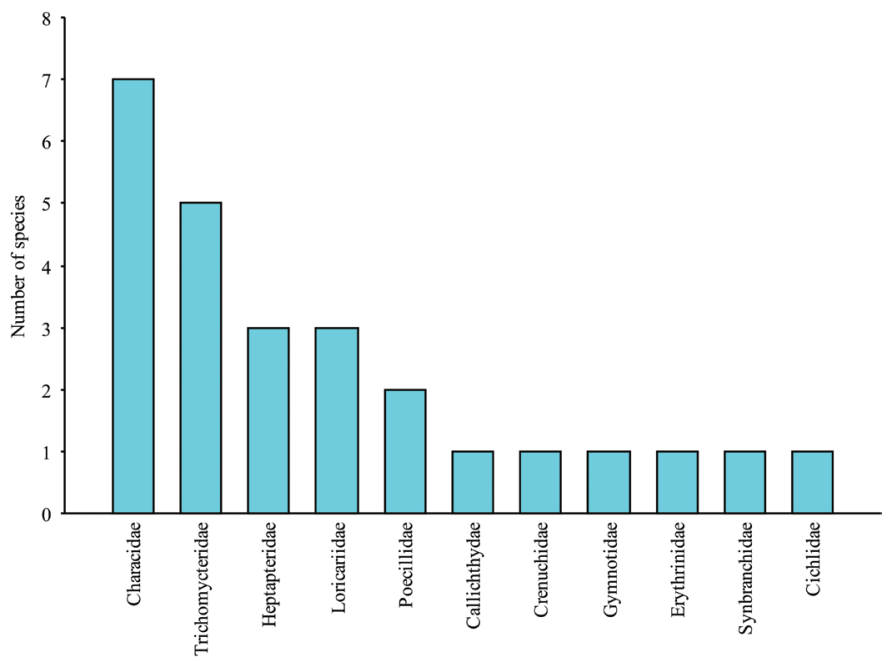

Figure 6. Specific richness to fish families recorded in eight streams of the lower Iguaçu River basin.

but at its high course (Ingenito et al. 2004, Abilhoa et al. 2008) and apparently to entire Paraná basin (Agostinho \& Júlio-Júnior 1999, Graça \& Pavanelli 2007, Langeani et al. 2007), to Amazonas drainages (Sabino \& Zuanon 1998, Albert \& Reis 2011) and overall neotropics (Reis et al. 2003). According to Albert \& Reis (2011) the predominance of Siluriformes and Characiformes in neotropical ichthyofauna could be related to Gondwana vicariant processes, isolating in South and Central America few high phylogenetic clades, but that evolved and diversified broadly at the region. Like in the present study, where $80.8 \%$ of species were Siluriformes or Characiformes and the others orders compassing only one or two species, the predominance of Siluriformes and Characiformes seems to be still more exacerbate in smaller water bodies (Frota et al. 2016b, Larentis et al. 2016), when compared to downstream courses and reservoirs.
Characidae with a great number of smaller sized and generalists foraging species (sensu Castro 1999, Abelha et al. 2001), normally have co-dominated with armored dwellers Loricariidae (Castro et al. 2003, Araújo et al. 2011, Hoffmann et al. 2015, Vidotto-Magnoni et al. 2015), or with catfishes Heptapteridae (Pereira et al. 2014), and eventually with Cichlidae (Gubiani et al. 2010), when non-native tilapias are present. However, similar to found herein, Trichomycteridae have been representative in low Iguaçu streams (Frota et al. 2016b, Larentis et al. 2016), probably by morphological adaptations of its species to dwelling in varied streams (Casatti 2003). Although, Trichomycterus sp. 1 and Trichomycterus sp. 2 still needs taxonomic description, five of the 11 species of the genus Trichomycterus mentioned by Baumgartner et al. (2010) were registered here. Except for T. mboycy, the others were recorded in most of the streams, regardless of the type of substratum or characteristics of the surroundings. It is worth noting that these species have very similar morphology and that color patterns of the body are commonly used to distinguish and identify species. However, Nascimento et al. (2017) verified ontogenetic variation of color pattern in T. davisi. Thereby, variation in color pattern within a population can cause doubt concerning species identification. In this sense, this group requires accurate taxonomic revision to confirm that this high number of species is restricted to Iguaçu River basin.

Previous studies conducted in streams of the same order in the lower Iguaçu River basin corroborate richness between eight and twelve species (Bifi et al. 2006, Larentis et al. 2016). The streams sampled presented distinct faunas with greater richness and occurrence of rarer species in forested streams. Astyanax bifasciatus and Trichomycterus stawiarski were the only two species found in all streams. These species are abundant and widely distributed in the Iguaçu River basin, and especially the first, is considered as polluted habitat bioindicator (Bueno-Krawczyk et al. 2015, Nimet et al. 2017). Ancistrus mullerae is also high abundant occurring in all streams except in S8. This species appears to be widely distributed in the main channel of the lower Iguaçu River, and was recorded in other surveys in the region (Bifi et al. 2006, Bifi et al. 2009, Larentis et al. 2016). On the other hand, many species occur in only a single site, as for example, A. dissimilis and Corydoras carlae that occurred in $\mathrm{S} 1$, a stream inserted inside the Iguaçu National Park; Bryconamericus pyahu and T. mboycy at S2 (marginal to the park) and Hoplias sp. 1 in S6 (private conservation unit). Heptapterus sp. was recorded only in the S7, a stream with rocky bottom and human occupation (i.e. houses and farming animals) near the sampled area. Characidium travassosi occurred exclusively in S8. This species has a fusiform body and well-developed fins that provide great balance, even in waters of high current. Among these seven species, except for A. lacustris and C. travassosi, the others were exclusive to forested streams and are endemic to Iguaçu basin (Baumgartner et al. 2012).

The main threats in continental waters are habitat change and species introductions (Pelicice et al. 2017), and these are also imminent in the Iguaçu River basin (Baumgartner et al. 2012). In this study, it was verified higher occurrence of non-native species in streams with greater rural influence. Among the four species considered to be non-native (about 15\%), two are reported to be used as baits (Gymnotus sylvius and 
Synbranchus marmoratus) (Baumgartner et al. 2012). Poecilia reticulata was introduced in Brazil for combating mosquito larvae and today is widespread in most streams, especially those more degraded (Pereira et al. 2014). Contrary, Oreochromis niloticus was the only non-native species recorded in a stream located in a conservation unit (S6). It should be emphasized, however, that this occurrence may be the result of accidental escapes from fish farming in the vicinity of the collection point, a situation that is very common in other streams in the region.

Four species were identified only at the genus level and followed the descriptions proposed by Baumgartner et al. (2010). Hoplias sp. 1 belongs to the complex of species currently identified as Hoplias malabaricus, widely distributed throughout Latin America. According to Baumgartner et al. (2010), this species has frequent occurrence in the Iguaçu River basin and comparative studies with the congeners from the adjacent basins (Paraná River), indicate that it must be a different species. It differs of the species identified by Graça \& Pavanelli (2007) as Hoplias sp. 1 (from the upper Paraná River, and currently identified as Hoplias mbigua), by having a more robust head profile and by having the coloration pattern of the gular region uniformly dark $v s$. a lower head, with a concave dorsal profile, and the gular region with alternate black and white bands. The other species (Heptapterus sp., Trichomycterus sp. 1, Trichomycterus sp. 2) also is probably restricted to the basin of the Iguaçu River, and probably correspond to species not yet described, sense that they present morphological differences from their congeners currently described to the Iguaçu River basin and also to other basins of Paraná system. Thereby, the occurrence of these four species, as well as the presence of many similar species (species complex of Astyanax and Trichomycterus), reinforce the urgency of accurate taxonomic revision and comparison with samples from other river basins.

Our findings highlight the need to improve the inventories of fish fauna, especially with greater spatial coverage, seasonal collections and in streams with different physiographic characteristics to confirm a restricted occurrence of fish fauna to headwater streams of the lower Iguaçu River basin. In this context, this study is important not only to document fish richness, which can included new species, but also to guide and/or support management and conservation of aquatic systems.

\section{Acknowledgments}

We thank the Universidade Estadual do Oeste do Paraná for providing logistical support for sampling. We also are deeply grateful to researchers Elaine Antoniassi Luiz Kashiwaqui e Suelen Pini for helping to identify the fish species; to Jardel Nimet for the aid in the field collections; to researchers of the Ichthyology Collection of Núcleo de Pesquisas em Limnologia, Ictiologia e Aquicultura, of the Universidade Estadual de Maringá, in special to Carla Simone Pavanelli for the identification of Hoplias sp. 1 and Cláudio Zawadzki, for helping to identify the Loricariidae.

\section{Author Contributions}

Rosilene Luciana Delariva, Mayara Pereira Neves: substantial contribution in the concept and design of the study;

Rosilene Luciana Delariva, Mayara Pereira Neves, Crislei Larentis, Bruna Caroline Kotz Kliemann, Mara Cristina Baldasso

Luciano Lazzarini Wolff: contribution to data collection;
Rosilene Luciana Delariva, Luciano Lazzarini Wolff, Mayara Pereira Neves, Crislei Larentis, Bruna Caroline Kotz Kliemann, Mara Cristina Baldasso: contribution to data analysis and interpretation;

Rosilene Luciana Delariva, Luciano Lazzarini Wolff, Crislei Larentis: contribution to manuscript preparation;

Rosilene Luciana Delariva, Luciano Lazzarini Wolff: contribution to critical revision, adding intelectual content.

\section{Conflicts of Interest}

The authors declare that they have no conflict of interest related to the publication of this manuscript.

\section{References}

ABELHA, M.C.F., AGOSTINHO, A.A. \& GOULART, E. 2001. Plasticidade trófica em peixes de água doce. Acta Sci. Anim. Sci. 23(2):425-434. http:// dx.doi.org/10.4025/actascibiolsci.v23i0.2696

ABELL, R., THIEME, M.L., REVENGA, C., BRYER, M., KOTTELAT, M., BOGUTSKAYA, N., COAD, B., MANDRAK, N., CONTRERASBALDERAS, S., BUSSING, W., STIASSNY, M.L.J., SKELTON, P., ALLEN, G.R., UNMACK, P., NASEKA, A., NG, R., SINDORF, N., ROBERTSON, J., ARMIJO, E., HIGGINS, J.V., HEIBEL, T.J., WIKRAMANAYAKE, E., OLSON, D., LÓPEZ, H.L., REIS, R.E., LUNDBERG, J.G., SABAJ-PÉREZ, M.H. \& PETRY, P. 2008. Freshwater Ecoregions of the World: A new map of biogeographic units for freshwater biodiversity conservation. BioScience 58(5):403-414. https://doi. org/10.1641/B580507

ABILHOA, V., DUBOC, L.F., \& DE AZEVEDO FILHO, D.P. 2008. A comunidade de peixes de um riacho de Floresta com Araucária, alto rio Iguaçu, sul do Brasil. Rev. Bras. Zool. 25(2):238-246. http://dx.doi. org/10.1590/S0101-81752008000200012

AGOSTINHO, A.A. \& GOMES, L.C. 1997. Reservatório de Segredo: bases ecológicas para o manejo. Eduem, Maringá.

AGOSTINHO, A.A., GOMES, L.C., SANTOS, N.C., ORTEGA, J.C. \& PELICICE, F.M. 2016. Fish assemblages in Neotropical reservoirs: Colonization patterns, impacts and management. Fish. Res. 173(1):26-36. https://doi.org/10.1016/j.fishres.2015.04.006

AGOSTINHO, A.A., GOMES, L.C., SUZUKI, H.I. \& JÚLIO JR., H.F. 2003. Migratory fishes of the upper Paraná River Basin, Brazil. In Migratory fishes of South America: biology, fisheries and conservation status (J. Carolsfeld, B. Harvey, C. Ross, \& A. Baer, eds). World Fisheries Trust, Canada, p.19-98.

AGOSTINHO, A.A. \& JÚLIO JR, H.F. 1999. Peixes da bacia do Alto rio Paraná. In Estudos ecológicos de comunidades de peixes tropicais (R.H. LoweMcConnell, ed.). Edusp, São Paulo, p. 374-400.

AGOSTINHO, A.A., PELICICE, F.M. \& GOMES, L.C. 2008. Dams and the fish fauna of the Neotropical region: impacts and management related to diversity and fisheries. Braz. J. Biol. 68(4):1119-1132. http://dx.doi.org/10.1590/ S1519-69842008000500019

ALBERT, J.A. \& REIS, R.E. 2011. Historical biogeography of Neotropical freshwater fishes. University of California Press, Berkeley and Los Angeles.

ANEEL. 2017. http://www2.aneel.gov.br/cedoc/dsp2003863.pdf. (last access at $20 / 09 / 2017$ )

ARAÚJO, M.I., DELARIVA, R.L., BONATO, K.O. \& SILVA, J.C. 2011. Fishes in first order stream in Ivaí River drainage basin, upper Paraná River Basin, Paraná state, Brazil. Check List 7(6):774-777 https://doi.org/10.15560/11023

BAUMGARTNER, D., BAUMGARTNER, G., PAVANELLI, C.S., SILVA, P.R.L., FRANA, V.A., OLIVEIRA, L.C. \& MICHELON, M.R. 2006. Fish, Salto Osório Reservoir, rio Iguaçu basin, Paraná State, Brazil. Check List 2(1):1-4. http://dx.doi.org/10.15560/2.1.1

BAUMGARTNER, G., PAVANELLI, C.S., BAUMGARTNER, D., BIFI, A.G., DEBONA, T. \& FRANA, V.A. 2012. Peixes do baixo Rio Iguaçu. Eduem, Maringá. 
BIFI, A.G., BAUMGARTNER, D., BAUMGARTNER, G., FRANA, V.A. \& DEBONA, T. 2006. Composição específica e abundância da ictiofauna do rio dos Padres, bacia do rio Iguaçu, Brasil. Acta Sci., Biol. Sci. 28(3):203211. http://dx.doi.org/10.4025/actascibiolsci.v28i3.193

BIFI, A.G., PAVANELLI, C.S. \& ZAWADZKI, C.H. 2009. Three new species of Ancistrus Kner, 1854 (Siluriformes: Loricariidae) from the Rio Iguaçu basin, Paraná State, Brazil. Zootaxa 2275:41-59. doi.org/10.5281/zenodo.191064

BUENO-KRAWCZYK. A.C.D., GUILOSKI, I.C., PIANCINI, L.D.S., AZEVEDO, J.C., RAMSDORF, W.A., IDE, A.H., GUIMARÃES, A.T.B., CESTARI, M.M. \& SILVA DE ASSIS, H.C. 2015. Multibiomarker in fish to evaluate a river used to water public supply. Chemosphere 135:247-264. http://dx.doi.org/10.1016/j.chemosphere.2015.04.064

CAMPOS, J. B. 1998. Desmatamentos no Paraná. Cadernos da Biodiversidade $1(1): 1-2$.

CASATTI, L. 2003. Biology of a catfish, Trichomycterus sp. (Pisces, Siluriformes), in a pristine stream in the Morro do Diabo State Park, Southeastern Brazil. Stud. Neotrop. Fauna E. 38(1):105-110. http://www. tandfonline.com/doi/pdf/10.1076/snfe.38.2.105.15928

CASTRO, R.M.C. 1999. Evolução da ictiofauna de riachos Sul-Americanos: Padrões gerais e possíveis processos casuais. In Ecologia de Peixes de Riachos: Estado Atual e Perspectivas (E.P. Caramaschi, R. Mazzoni, C.R.S.F. Bizerril \& P.R. Peres-Neto, eds). Oecol. Bras. Rio de Janeiro, p.139-155.

CASTRO, R.M.C., CASATTI, L., SANTOS, H.F., FERREIRA, K.M., RIBEIRO, A.C., BENINE, R.C., DARDIS, G.Z.P., MELO, A.L.A., STOPIGLIA, R., ABREU, T.X., BOCKMANN, F.A., CARVALHO, M., GIBRAN, F.Z. \& LIMA, F.C.T. 2003. Estrutura e composição da ictiofauna de riachos do rio Paranapanema, Sudeste e Sul do Brasil. Biota Neotrop. 3(1):1-14. http:// dx.doi.org/10.1590/S1676-06032003000100007 (last access at 20/09/2017)

CETRA, M., BARRELLA, W., LANGEANI, F., MARTINS, A.G., MELLO, B.J. \& ALMEIDA, R.S. 2012. Fish fauna of headwater streams that cross the Atlantic Forest of south São Paulo state. Check List 8(3):421-425. http:// dx.doi.org/10.15560/8.3.421

CETRA M., MATTOX, G.M.T., FERREIRA, F.C., GUINATO, R.B., SILVA, F.V., PEDROSA, M. 2016. Headwater stream fish fauna from the Upper Paranapanema River basin. Biota Neotrop. 16(3):e20150145. http://dx.doi. org/10.1590/1676-0611-BN-2015-0145 (last access at 20/09/2017)

DELARIVA, R.L. \& SILVA, J.C. 2013. Fish fauna of headwater streams of Perobas Biological Reserve, a conservation unit in the Atlantic Forest of the Northwestern Paraná State, Brazil. Check List 9(3):549-554. http:// dx.doi.org/10.15560/9.3.549

DELARIVA, R.L., HAHN, N.S. \& KASHIWAQUI, E.A.L. 2013. Diet and trophic structure of the fish fauna in a subtropical ecosystem: impoundment effects. Neotrop. Ichthyol. 11(4):891-904. http://dx.doi.org/10.1590/S167962252013000400017

DUKE ENERGY. 2008. Peixes do rio Paranapanema. Horizonte Geográfico, São Paulo.

FROTA, A., DEPRÁ, G.C., PETENUCCI, L.M. \& GRAÇA, W.J. 2016a Inventory of the fish fauna from Ivaí River basin, Paraná State, Brazil. Biota Neotrop. 16(3):e20150151. http://dx.doi.org/10.1590/1676-0611BN-2015-0151

FROTA, A., GONÇALVES, E.V.R., DEPRÁ, G.C. \& GRAÇA, W.J. 2016b. Inventory of the ichthyofauna from the Jordão and Areia river basins (Iguaçu drainage, Brazil) reveals greater sharing of species than thought. Check List 12(6):1995. http://dx.doi.org/10.15560/12.6.1995

GARAVELLO, J.C. \& SAMPAIO, F.A.A. 2010. Five new species of genus Astyanax Bird \& Girard, 1854 from Rio Iguaçu, Parana, Brazil (Ostariophysi, Characiformes, Characidae). Braz. J. Biol. 70(3):847-865. http://dx.doi. org/10.1590/S1519-69842010000400016

GARAVELLO, J.C., BRITSKI, H. A. \& ZAWADZKI, C.H. 2012. The cascudos of the genus Hypostomus Lacépède (Osteichthyes: Loricariidae) from the rio Iguaçu basin. Neotrop. Ichthyol. 10(2):263-283. http://dx.doi.org/10.1590/ S1679-62252012000200005
GARAVELLO, J.C., PAVANELLI, C.S. \& SUZUKI, H.I. 1997. Caracterização da ictiofauna do rio Iguaçu. In Reservatório de Segredo: bases ecológicas para o manejo. (A.A. Agostinho \& L.C. Gomes, eds). Eduem, Maringá, p.61-84.

GÉRY, J. 1969. The freshwater fishes of South America. In Biogeography and Ecology in South-America (E.J. Fittkau, J. Illies, H. Klinge, G.H. Schwabe \& H. Sioli, eds). The Hague, Junk, p.828-848.

GRAÇA, W.J. \& PAVANELLI, C.S. 2007. Peixes da planície de inundação do alto rio Paraná e áreas adjacentes. Eduem, Maringá.

GUBIANI, E.A., DAGA, V.S., FRANA, V.A. \& GRAÇA, W.J. 2010. Fish, Toledo urban streams, São Francisco Verdadeiro River drainage, upper Paraná River basin, state of Paraná, Brazil. Check List 6(1):45-48. https:// doi.org/10.15560/6.1.045

HOFFMANN, A.C., NASCIMENTO, R.H.C. \& SHIBATTA, O.A. 2015. Fish fauna from tributaries throughout the Tibagi River basin, upper Paraná, basin, Brazil. Check List 11(6):1-12. http://dx.doi.org/10.15560/11.6.1815

IBGE. 2015. Instituto Brasileiro de Geografia e Estatística. Indicadores de desenvolvimento sustentável (IDS). Brasil.

INGENITO, L.F.S., DUBOC, L.F. \& ABILHOA, V. 2004. Contribuição ao conhecimento da ictiofauna da bacia do alto rio Iguaçu, Paraná, Brasil. Arquivos de Ciências Veterinárias e Zoológicas da UNIPAR 7(1):23-36. https://doi.org/10.25110/arqvet.v7i1.2004.540

LANGEANI, F., CASTRO, R.M.C., OYAKAWA, O.T., SHIBATTA, O.A., PAVANELLI, C.S. \& CASATTI, L. 2007. Diversidade da ictiofauna do Alto Rio Paraná: composição atual e perspectivas futuras. Biota Neotrop. 7(3):1-17. http://dx.doi.org/10.1590/S1676-06032007000300020

LARENTIS, C., DELARIVA, R.L., GOMES, L.C., BAUMGARTNER, D., RAMOS, I.P. \& SEREIA, D.A.O. 2016. Ichthyofauna of streams from the lower Iguaçu River basin, Paraná State, Brazil. Biota Neotrop. 16(3):e20150117. http://dx.doi.org/10.1590/1676-0611-BN-2015-0117

MALABARBA, L.R., REIS, R.E., VARI, R.P., LUCENA, Z.M. \& LUCENA, C.A. 1998. Phylogeny and Classification of Neotropical Fishes. Edipucrs, Porto Alegre.

MARCENIUK, A.P., HILSDORF, A.W.S. \& LANGEANI, F. 2011. The ichthyofauna from the headwaters of the rio Tietê, São Paulo, Brazil Biota Neotrop. 11(3):217-236. http://dx.doi.org/10.1590/S167606032011000300020

MIRANDE, J.M. 2009. Weighted parsimony phylogeny of the family Characidae (Teleostei: Characiformes). Cladistics 25: 574-613. https://doi.org/10.1111/ j.1096-0031.2009.00262.x

NASCIMENTO, R.H.C., FRANTINE-SILVA, W., SOUZA-SHIBATTA, L., SOFIA, S.H., FERRER, J. \& SHIBATTA, O.A. 2017. Intrapopulational variation in color pattern of Trichomycterus davisi (Haseman, 1911) (Siluriformes: Trichomycteridae) corroborated by morphometrics and molecular analysis. Zootaxa 4290:503-518. http://dx.doi.org/10.11646/ zootaxa.4290.3.5

NELSON, J.S. 2006. Fishes of the world. John Wiley \& Sons, New York.

NEVES, M.P., DEVARIVA, R.L. \& WOLFF, L.L. 2015. Diet and ecomorphological relationships of an endemic, species-poor fish assemblage in a stream in the Iguaçu National Park. Neotrop. Ichthyol. 13(1):245-254. http://dx.doi. org/10.1590/1982-0224-20140124

NIMET, J., GUIMARÃES, A.T.B. \& DELARIVA, R.L. 2017. Use of Muscular Cholinesterase of Astyanax bifasciatus (Teleostei, Characidae) as a Biomarker in Biomonitoring of Rural Streams. Bull. Environ. Contamin. Toxicol. 99(2):232-238. https://doi.org/10.1007/s00128-017-2111-9

NOGUEIRA, C., BUCKUP, P.A., MENEZES, N.A., OYAKAWA, O.T., KASECKER, T.P., RAMOS NETO, M.B. \& SILVA, J.M.C. 2010 Restricted-range fishes and the conservation of Brazilian freshwaters. Plos One 5(6):e11390. https://doi.org/10.1371/journal.pone.0011390

OYAKAWA, O.T. \& MENEZES, N.A. 2011. Checklist of fresh water fishes from São Paulo State, Brazil. Biota Neotrop. 11(1a):1-13. http://dx.doi. org/10.1590/S1676-06032011000500002 
PAROLIN, M., RIBEIRO, C.V. \& LEANDRINI, J.A. 2010. Abordagem ambiental interdisciplinar em bacias hidrográficas no Estado do Paraná. Editora da Fecilcam, Campo Mourão.

PELICICE, F.M., AZEVEDO-SANTOS, V.M., VITULE, J.R.S., ORSI, M.L., LIMA-JUNIOR, D.P., MAGALHÃES, A.L.B., POMPEU, P.S., PETRERE JR, M. \& AGOSTINHO, A.A. 2017. Neotropical freshwater fishes imperilled by unsustainable policies. Fish and Fisheries, 1-15. https://doi.org/10.1111/ faf. 12228

PEREIRA, A.L., RIBEIRO, V.R., GUBIANI, E.A., ZACARKIM, C.E. \& CUNICO, A.M. 2014. Ichthyofauna of urban streams in the western region of Paraná state, Brazil. Check List 10(3):550-555. http://dx.doi. org $/ 10.15560 / 10.3 .550$

PETRI, S. \& FULFARO, V.J. 1983. Geologia do Brasil: Fanerozóico. TA Queiroz, Editor, São Paulo.

REIS, R.E., KULLANDER, S.O. \& FERRARIS JR., C.J. 2003. Check list of freshwater fishes of South and Central America. Edipucrs, Porto Alegre.

SABINO, J. \& ZUANON, J. 1998. A stream fish assemblage in Central Amazonia: distribution, activity patterns and feeding behavior. Ichthyol. Explor. Freshw. 8(3):201-210.

SAMPAIO, F.A.A. 1988. Estudos Taxonômicos Preliminares dos Characiformes (Teleostei, Ostariophysi) da Bacia do Rio Iguaçu, com comentários sobre o endemismo dessa fauna. Dissertação de mestrado, Universidade Federal de São Carlos, São Carlos.

SEMA, Secretaria de Estado do Meio Ambiente e Recursos Hídricos. 2013. Bacias Hidrográficas do Paraná. Série Histórica, Curitiba.
UNESCO, United Nations Educational, Scientific and Cultural Organization 2012. World Heritage Committee. Report: $36^{\text {th }}$ Session. WHC-12/36. $\mathrm{COM} / 7 \mathrm{~B}$. Add. Convention Concerning the Protection of the World Cultural and Natural Heritage. Saint-Petersburg. Available from http://whc.unesco. org/archive/2012/whc12-36com-7BAdd-en.pdf (last access at 20/09/2017)

VIDOTTO-MAGNONI, A.P., GARCIA, D.A.Z., COSTA, A.D.A., SOUZA, J.G., YABU, M.H.S., ALMEIDA, F.S. \& ORSI, M.L. 2015. Ichthyofauna of streams of the Lower Paranapanema River basin, state of Paraná, Brazil. Check List 11(5): 1-8. http://dx.doi.org/10.15560/11.5.1756

VITULE, J.R.S. \& ABILHOA, V.A. 2003. Composição da ictiofauna na bacia hidrográfica do rio Piraquara, alto rio Iguaçu, Região Metropolitana de Curitiba, Paraná, Brasil. Estudos de Biologia 25(52): 43-49.

WOLFF, L.L., ABILHOA, V., RIOS, F.S. \& DONATTI, L. 2009. Spatial, seasonal and ontogenetic variation in the diet of Astyanax aff. fasciatus (Ostariophysi: Characidae) in an Atlantic Forest river, Southern Brazil. Neotrop. Ichthyol. 7(2):257-266. doi:10.1590/S1679-62252009000200018

YAMAMOTO, F., PEREIRA, M., LOTTERMANN, E. SANTOS, G.S., STREMEL, T.R.O., DORIA, H.B., GUSSO-CHOUERI, P., CAMPOS, S.X., ORTOLANI-MACHADO, C.F. CESTARI, M.M., FILIPAK NETO, F., AZEVEDO, J.C.R. \& OLIVEIRA RIBEIRO, C.A. 2016. Bioavailability of pollutants sets risk of exposure to biota and human population in reservoirs from Iguaçu River (Southern Brazil). Environ. Sci. Pollut. Res. 23(18):18111-18128. https://doi.org/10.1007/s11356-016-6924-6

ZAWADZKI, D.H., RENESTRO, E. \& BINI, L.M. 1999. Genetic and morphometric analysis of three species of the genus Hypostomus Lacépède, 1803 (Osteichthyes: Loricariidae) from the Rio Iguaçu basin (Brazil). Rev. Suisse Zool. 106(1):91-105. https://doi.org/10.5962/bhl.part.80072

Received: 04/10/2017

Revised: 27/04/2018

Accepted: 05/05/2018

Published online: 21/06/2018 